\title{
Working in Public Administration During Nonwork Time During the COVID-19 Pandemic
}

\author{
Špela Mar \\ University of Ljubljana, Faculty of Public Administration, Slovenia \\ spela.mar@fu.uni-lj.si \\ https://orcid.org/0000-0002-1698-4273 \\ Jernej Buzeti \\ University of Ljubljana, Faculty of Public Administration, Slovenia \\ jernej.buzeti@fu.uni-lj.si \\ https://orcid.org/0000-0001-8985-8190
}

Received: 1. 3. 2021

Accepted: 7. 5. 2021

\section{ABSTRACT}

With the outbreak of Covid-19, a pandemic was declared in March 2020 and countries introduced various measures to overcome it. As a result, employees worked more intensively from home with the use of information and communication technologies (ICT), which significantly affected the way of work, the length of the working day, and the time reserved for rest. The purpose of this article is to examine whether, during the pandemic, public employees in the Slovenian public administration worked during nonwork time. This is the first research of this kind in the Slovenian public administration. The research applied the quantitative method and an online questionnaire conducted in February 2021, whereby data from 1676 public administration employees were obtained. The results of the research show that at the time of the Covid-19 pandemic, $80 \%$ of the respondents performed work during nonwork time. In fact, public employees quite often worked late in the afternoon after working hours and on weekends. Interestingly, about $10 \%$ of public employees even worked during annual leave and sick leave. The results of the research contribute to theoretical and practical knowledge about work related activities during nonwork time.

Keywords: Covid-19, information and communication technology (ICT), public administration, public employees, work during nonwork time, work from home 


\section{Introduction}

Organizations and employees need to constantly adapt to changes that are increasingly affecting the distribution of working time and performance. Proper organization and duration of working time and rest time are essential for organizations and employees as well as their well-being and health, and in general for the development of society (Lutz et al., 2020; Thörel et al., 2020).

Following the declaration of a global pandemic, due to the outbreak of COVID-19 (SARS-CoV-2) in March 2020, measures to protect human health and prevent the spread of the virus and reduce the consequences were introduced. Organizations have changed their ways of organizing work, working conditions and processes, and many employees have started working from home (ILO, 2020). In July 2020, the European Union (EU27) had the largest number of employees working from home in the service sector, especially in the fields of education, finance and public administration, and slightly less in the fields of health, transport and agriculture (Eurofound., 2020, pp. 3132). Public servants in public administration in Slovenia were no exception. As Buzeti (2020, p. 53) points out, employees in organizations respond differently to situations in the work environment and it is therefore not surprising that during an epidemic period (Eurofound, 2021; Eurofound, 2020; DeFilippis et al., 2020; McCulley, 2020, cited in ILO, 2020; Reisenwitz, 2020, cited in ILO, 2020) the working hours of employees in general have not only lengthened, employees also perform work during the time set aside for their rest.

The purpose of this article is to examine whether public servants in the Slovenian public administration perform work during nonwork time during the COVID-19 (SARS-CoV-2) epidemic. We are interested in how many times per week, and when exactly employees work during nonwork time. The main goal of the article is to present the results and findings of a survey conducted in February 2021 with public servants in the Slovenian public administration.

The article is structured in the following way. The initial part presents an introduction, a review of the literature on performing work during nonwork time and a hypothesis. This is followed by a presentation of the methodology, which presents the research procedures, the target group that was included in the research and the instrument we used to collect the data. Then we present the results of a survey on the performance of public servants during nonwork time during the COVID-19 (SARS-CoV-2) epidemic in public administration. The last part of the article presents the discussion aspect of the authors of the article on the content of the research results and the conclusion.

\section{Work during Nonwork Time}

Working time and rest time can be studied from different perspectives, such as sociological, legal and economic, organizational and health aspects. At the same time, working time and rest time represent one of the most important legal institutes of employment. For organizations and employees, the dura- 
tion and organization of working hours as well as rest periods are essential, but they are increasingly changing due to various factors.

Article 2 of Directive 2003/88/EC stipulates that working time contains elements such as, the worker works and is available to the employer and performs his work tasks and duties. It is stipulated that the maximum weekly working time including overtime, lasts 48 hours. In Slovenia, the Employment Relationship Act (ZDR-1) stipulates in Article 142 that, on average, full-time work may not exceed 40 hours per week (European Commission, 2017, p. 25). In the event that the employer orders the employee to work after working hours, this period is assessed according to the rules for overtime work, which is counted as working time (Šenčur Peček, 2017, p. 169, Article 143 of ZDR-1). Directive $2003 / 88 / E C^{1}$ and $Z D R-1^{2}$ define a rest period, namely a minimum daily rest period of 11 consecutive hours between two working days and a minimum weekly rest period of 35 uninterrupted hours. The purpose of work rest is to keep workers away from the work environment for several hours and to eliminate fatigue associated with the performance of work tasks. By concluding an employment relationship, employees are also entitled to annual leave, which is intended for their relaxation and entertainment. Under Directive 2003/88/ EC ${ }^{3}$ and ZDR- ${ }^{4}{ }^{4}$, workers are entitled to annual leave for a minimum period of four weeks (European Commission, 2017, pp. 28-30).

In practice we can see that many employees perform their work tasks during the time set aside for their rest. A similar finding has been confirmed in the literature and sources (Eurofound, 2021; Eurofound, 2020; DeFilippis et al., 2020; McCulley, 2020, cited in ILO, 2020; Reisenwitz, 2020, cited in ILO, 2020; ILO and Eurofound, 2019; Gschwind and Vargas, 2019; Vayre and Vonthron, 2019; Houdmont et al., 2018), where discussions on working time focus on its expansion into employee rest time (early morning, late evening, weekends and holidays and during sick leave), for which we will use the term "nonwork time". Despite reports from Eurofound (2020) and ILO Monitor (2020) of deteriorating labor market conditions and job losses worldwide and reductions in working hours, employees are at the time of the COVID-19 pandemic working during nonwork time (Eurofound, 2021; Eurofound, 2020; DeFilippis et al., 2020; McCulley, 2020, cited in ILO, 2020, p. 5; Reisenwitz, 2020, cited in ILO, 2020, p. 6).

According to statistics, in the period April-May 2020 during the COVID-19 (SARS-CoV-2) pandemic 53.5\% of employees work during nonwork time and in the period June-July 53.7\% in the European Union (EU27). In Slovenia, however, slightly more employees than the EU27 average worked during nonwork time, $56.3 \%$ of surveyed employees in the period April-May 2020 and $59.1 \%$ of surveyed employees in the period June-July (Eurofound, 2021).

In Europe, North America and the Middle East, the way of work and the frequency of communication have changed among employees who worked from

1 from Article 3 to Article 5.

2 in Article 155 and in Article 156 of ZDR-1.

3 Article 7.

4 from Article 159 to Article 162. 
home during the COVID-19 pandemic (DeFilippis et al., 2020). Employees had to adjust their work schedules, the length of meetings was shortened, and their number and the number of employees present at meetings increased. In their work, they also communicated more frequently via email. Employee working hours increased by an average of 48.5 minutes (8.2\%) during the COVID-19 epidemic (DeFilippis et al., 2020).

The ILO report (2020) presents data that working from home, during the COVID-19 pandemic is more demanding compared to other flexible forms of working (e.g. teleworking, mobile working hours, etc.), as it is compulsory compliance, and many employees have never worked from home before. This is important for our research, as working from home is often associated with working during nonwork time, and research shows that in EU27 countries, employees worked longer (McCulley, 2020, cited in ILO, 2020). Thus, during the COVID-19 (SARS-CoV-2) pandemic in the period June-July 2020, employees in the EU27 worked on average 41.6 hours per week, and in Slovenia 51.3 hours (Eurofound, 2021). Due to the physical separation of work teams, the performance of work tasks of employees took place through information and communication technology (ICT), as a result of which employees were constantly available to superiors, co-workers and customers. Employees spent more time on virtual meetings. Because they took care of dependent family members when working, employees found it more difficult to complete tasks within normal working hours, so they worked during nonwork time, for example early in the morning or late in the evening (Reisenwitz, 2020, cited and ILO, 2020).

Overtime work is not unique to the COVID-19 pandemic, but research prior to the declared epidemic found that employees work during nonwork time (ILO and Eurofound, 2019; Gschwind and Vargas, 2019; Vayre and Vonthron, 2019; Houdmont et al., 2018). ILO and Eurofound (2019) found that employees in the European Union (EU) worked during nonwork time (including during annual leave) in order to meet work requirements. Such behavior is typical of employees in management positions and of experts in the field of education and agriculture. Research shows that more full-time employees (14\%) performed part-time work tasks than part-time employees (10\%). Respondents from service activities (construction, transport, commercial, agriculture) reported in the survey that their rest time was less than 11 hours at least once a month between two working days.

In their research, Vayre and Vonthron (2019) wanted to define the consequences of the use of information and communication technology (ICT) and the internet on the performance of employees' work. The survey included executives at various levels and measured their use of the web for work purposes within and out of normal working hours and the workplace. In doing so, they wanted to find out how managers perceive the impact of work on private life, work commitment and attitude towards the internet. With the results, they confirmed that the use of ICT provided by the employer and the use of the internet for private and work purposes are related to the intensity of their use and the place of work and time periods. The very intensive, extensive and po- 
rous use of the internet promotes the permeability of the boundaries between the professional and private lives of leaders. Respondents confirmed that the intensive use of ICT and the internet has reduced their commitment to work and leadership power, while increasing their addiction to the internet.

What was also interesting is the analysis of research conducted by Gschwind and Vargas (2019), was that they found that teleworkers usually work longer than those who work at the location of the employer, from a database of research and national reports of European countries. In doing so, employees working remotely in research confirmed that their working hours are longer, averaging 44.5 hours per week (Hooftman et al., 2015; Trygg, 2014; Tipping et al., 2012; Ojala, 2011; INSHT, 2011; Walrave and De Bie, 2005, cited in Gschwind and Vargas, 2019, pp. 48-50). Teleworkers also reported that they were contacted during nonwork time in connection with work tasks, mostly via email and business phone calls (Sutela and Lehto 2014; Randstad, 2012, cited in Gschwind and Vargas, 2019, pp. 48-50). Employees confirmed that they are available to co-workers and clients during nonwork time every day or frequently (Unionen, 2013, cited in Gschwind and Vargas, 2019, pp. 48-50). On the other hand, teleworkers engage in private activities during breaks during working hours, such as household chores and childcare (Walrave and De Bie, 2005, cited in Gschwind and Vargas, 2019, pp. 48-50). Because most teleworkers do not follow "typical work schedules" as they start work before or after office hours, in the evenings and on weekends, their working hours are longer. This leads to so-called "time porosity", which includes the period of work during nonwork time (including location) (Genin, 2016; Hooftman et al., 2015; INSHT 2011; Anttila et al., 2009, cited in Gschwind and Vargas, 2019, pp. 48-50).

Houdmont et al. (2018) found in a study that employees of the Police Federation of England and Wales performed work during nonwork time, during annual leave and also during sick leave. Based on the results of the research, they confirmed all three dimensions of the concept of "leaveism" first mentioned in 2013 by Hesketh and Cooper. In case of health problems, the respondents used leave (dimension 1) instead of sick leave and performed work tasks during nonwork time, which they were not able to complete during working hours (dimension 2), as they were convinced that they would make up for missed work (dimension 3). Based on the results, the authors confirmed that the second and third dimensions of "leaveism" are more characteristic of employees in managerial positions.

The data from the above research undoubtedly shows that employees work during nonwork time during the COVID-19 (SARS-CoV-2) epidemic. Therefore, based on the literature, we hypothesize that:

- Hypothesis 1: During the COVID-19 (SARS-CoV-2) epidemic, more than half of the surveyed public servants in public administration work during nonwork time.

- Hypothesis 2: Work during nonwork time during the COVID-19 (SARS-CoV-2) epidemic is performed by those public servants in the public administration whose workload has increased. 


\section{Methods}

\subsection{Procedure and Participants}

In order to obtain data for our research, we conducted a survey in the Slovenian public administration in February 2021. Data were collected using an online questionnaire. In our research we included public administration bodies and organizations, namely ministries with constituent bodies, government services, administrative units, local self-government and holders of public authority. Holders of public authorisation include natural and legal persons, and those classified in public administration include public agencies, public funds and some institutions, such as the Pension and Disability Insurance Institute of Slovenia, the Employment Service of Slovenia, and the Centers for Social Work, etc. (Tičar and Rakar, 2011). Public administration is functionally part of the decision-making process on public affairs, which takes place at the executive level, and in organizational terms it is a set of bodies and organizations that provide professional bases for political decision-making and directly implement political decisions (Virant, 2009, p. 18).

According to official data, the public administration employs $40.191^{5}$ public servants, who were our target group for the study. The sample of our research is represented by the data of 1676 respondents who participated in the research, which represents a $4.17 \%$ share of the entire population of public servants in the Slovenian public administration.

Table 1: Distribution of employees by the type of organisation and number of public servants in public administration in Slovenia

\begin{tabular}{|c|c|c|c|c|}
\hline \multirow[t]{2}{*}{$\begin{array}{l}\text { Type of public administration } \\
\text { organisation }\end{array}$} & \multicolumn{2}{|c|}{ Participants (sample) } & \multicolumn{2}{|c|}{$\begin{array}{c}\text { Number of public } \\
\text { servants in public } \\
\text { administration in Slovenia }\end{array}$} \\
\hline & $\mathrm{F}$ & $\%$ & $\mathrm{~F}$ & $\%$ \\
\hline State administration & 1138 & $67.9 \%$ & $28.958,47$ & $72 \%$ \\
\hline Local administration & 258 & $15.3 \%$ & $5.308,69$ & $13.2 \%$ \\
\hline Holders of public authorities & 280 & $16.8 \%$ & $5.923,94$ & $14.8 \%$ \\
\hline Total public administration & 1676 & $100 \%$ & 40.191 & $100 \%$ \\
\hline
\end{tabular}

Source: authors

Table 1 shows the distribution of respondents by type of organization in public administration in Slovenia. The sample of our research included $67.9 \%$ of employees in state administration, $15.3 \%$ in local self-government and $16.8 \%$ of employees in public authorities. The largest share in the sample structure of our survey is represented by officials, namely $55.4 \%$, in addition, $14 \%$ of officials in senior positions and $2.7 \%$ of officials in senior positions, $23.7 \%$ of

531 August 2020. Some data could not be obtained on the OPSI portal. 
professional and technical staff and $4.1 \%$ of professional and technical staff in a leading position.

Analysis of the survey sample by gender shows that $79.4 \%$ of women and $20.6 \%$ of men participated in the survey. The majority of respondents are between 45 and 54 years old (35.6\%) and between 35 and 44 years old (33.2\%), their average age is 46 years.

In the article, officials are treated as those public servants who perform public tasks directly related to the exercise of power or protection of public interest and professional and technical public servants who perform accompanying work in the field of personnel and material-financial operations, technical and similar work and other type of work that must be performed for the smooth implementation of public tasks of the body (Article 23 of the ZJU). According to the ZJU (Articles 80 to 83), the highest official positions are held by senior public servants, who exercise their powers in the body in accordance with the management and coordination and organization of work. These positions are Director General, Secretary General and Heads of Organizational Units in Ministries, Director and Heads of Organizational Units in Bodies within the Ministry, Head of Administrative Unit and Heads of Organizational Units in Administrative Units, Director and Heads of Organizational Units in Government Services and Director and Heads of Organizational Units as well as units in local community administrations.

\subsection{Measures}

In order to achieve the set goals and a more detailed analysis of the research data and the defined research problem, we used a quantitative research method. For empirical research, an online survey questionnaire ${ }^{6}$ was developed in the online tool $1 \mathrm{ka}$. In order to collect data in the public administration on the performance of public servants during nonwork time during the COVID-19 epidemic, three sets of questions were formulated in the questionnaire:

- the first set of questions ("Socio-demographic data"); covers seven short open-ended and closed-ended questions relating to the socio-demographic characteristics of respondents such as employment organization, gender, level of education, year of birth (age), length of service in the current employment organization, working time agreement in the employment contract and work area of employees. A questionnaire by Jernej Buzeti (2020) was used to obtain relevant socio-demographic data of public servants. We added questions about employment status ourselves.

- the second set of questions ("Work during COVID-19"); includes four short open-ended and closed-ended questions on the basis of which we wanted to find out where the respondents performed their work during the COVID-19 (SARS-CoV-2) epidemic, how the working hours of the respondents were determined and formed during the epidemic and if the time of

6 It is referred to as the Questionnaire on Extended Availability for Work of Public Servants during Nonwork Time with Causes at the Time of the COVID-19 epidemic. 
employees during the epidemic was lengthened, shortened or remained the same and whether the amount of work that employees managed to perform increased, remained at the same level as before the epidemic or decreased. The questions were summarized from the Eurofound pandemic survey COVID-197 (2020).

- the third set of questions ("Work during nonwork time"); deals with the performance of work during nonwork time of employees. It comprises of five open-ended and closed-ended questions that check the existence, frequency and period of out-of-hours work and the number of working contacts received and the use of information and communication technology (ICT) during non-working hours during the COVID-19 ${ }^{8}$ epidemic. The Eurofound Survey on the COVID-19 (2020) and the 6th Eurofound Survey on Working Conditions ${ }^{9}$ by Agnes Parent-Thirion et al. (2017).

We added questions about the extent of ICT use ourselves. The first two questions were closed-ended. Respondents answered the first question about the frequency of work during nonwork time ("How often do you work during nonwork time during the COVID-19 epidemic to meet work requirements?") with "Every day", "Every other day", "Once or twice a week", "Less often", "Never". Respondents who answered "Never" (meaning that during the COVID-19 epidemic they did not perform work tasks during nonwork time and did not respond to work requests during that time) finished with answering the online survey. The second question ("When do you usually work during nonwork time during the COVID-19 epidemic?"), respondents answered with "Early in the morning before the official start of working hours", "Afternoon after the end of official working hours", "Late in the evening", "During the weekend (Saturday, Sunday)", "During the day off (holiday)", "During the use of annual leave", "During sick leave". The third question "How many out-of-hours working contacts do you receive on average per week during the COVID-19 epidemic" was designed as an open type question, as we wanted to obtain data on the number of working contacts (e-mails, business phone calls, business shortcuts), messages (e.g. text messages, mobile apps, social networks and e-meetings on Zoom, MS Teams, Cisco Webex, Skype, etc.) of respondents during nonwork time per week. To this end, respondents themselves entered the number of working contacts received during nonwork time.

The fourth question "Which information and communication technology (ICT) do you use when performing work duties during nonwork time during the COVID-19 epidemic" was formulated as an open type question, as respondents answered on a five-point Likert scale ("1 - Never to 5 - Always") how often they use ICT in their work during nonwork time. They could also choose "Other", where respondents were able to enter ICT themselves in addition to the answers already offered. The fifth question investigated whether it happened at least once during the COVID-19 epidemic that the respondents had

7 Living, working and COVID-19.

8 Living, working and COVID-19.

9 6th European Working Conditions Survey. 
a daily rest period of less than 11 hours during two working days. Respondents answered "Yes" or "No". If the respondents recorded "Yes", we wanted to find out in the following sub-question, how many times a week their daily rest was not long enough.

Next, we are presenting an analysis of the obtained data from a survey on the performance of public servants during nonwork time in the Slovenian public administration during the COVID-19 epidemic (SARS-CoV-2).

\section{Results}

The survey was carried out to determine how often and when did public servants in Slovenian public administration at the time of the COVID-19 (SARSCoV-2) epidemic perform work tasks during nonwork time and whether during this time they responded to the working requests of superiors, colleagues and clients through ICT. The quantitative data obtained was processed in the SPSS programme as we wanted to obtain adequate, reliable and objective and accurate data on the work performance of public servants during nonwork time during the COVID-19 (SARS-CoV-2) epidemic. In addition we used the statistical method of the binominal test and Pearson's chi-square test. The binominal test verified whether public servants in the Slovenian public administration were working during nonwork time during the COVID-19 epidemic.

Table 2: Number of public servants surveyed working during nonwork time during the COVID-19 (SARS-CoV-2) epidemic

\begin{tabular}{|c|c|c|c|c|c|}
\hline Public servants & Category & N & $\begin{array}{c}\text { Observed } \\
\text { Prop. }\end{array}$ & $\begin{array}{c}\text { Test } \\
\text { Prop. }\end{array}$ & $\begin{array}{c}\text { Exact Sig. } \\
\text { (2-tailed) }\end{array}$ \\
\hline Group 1 & Yes & 1340 & 0.800 & 0.500 & 0.000 \\
\hline Group 2 & No & 336 & 0.200 & & \\
\hline Total & & 1676 & 1.000 & & \\
\hline
\end{tabular}

Source: authors

In the statistical analysis, the respondents were divided into two groups (Table 2) into those (group 1) who work during nonwork time, regardless of the frequency of performance, and those (group 2) respondents who never work during nonwork time during the COVID-19 epidemic. We then checked the proportions of those surveyed and found that $80 \%$ (1340) of respondents were working during nonwork time during the COVID-19 epidemic. During the COVID-19 epidemic, 20\% (336) of respondents never work during nonwork time. 
Table 3: Frequency of out-of-hours working hours of public servants during the COVID-19 (SARS-CoV-2) epidemic

\begin{tabular}{|l|c|c|}
\hline \multicolumn{1}{|c|}{ Frequency of work } & F & $\%$ \\
\hline Daily & 241 & $14.4 \%$ \\
\hline Every other day & 225 & $13.4 \%$ \\
\hline Once or twice per week & 488 & $29.2 \%$ \\
\hline Less often & 386 & $23 \%$ \\
\hline Never & 336 & $20 \%$ \\
\hline Total & 1676 & $100 \%$ \\
\hline
\end{tabular}

Source: authors

During the COVID-19 epidemic, most public servants (29\%) work during nonwork time once or twice per week, while at least (13.4\%) work during nonwork time every other day (Table 3).

Table 4: Non-working time periods of public servants during the COVID-19 (SARS-CoV-2) epidemic

\begin{tabular}{|l|c|c|}
\hline \multicolumn{1}{|c|}{ Time frames } & F & $\%$ \\
\hline Early in the morning before work & 367 & $21.9 \%$ \\
\hline After work & 957 & $57.1 \%$ \\
\hline Late in the evening & 527 & $31.4 \%$ \\
\hline Weekend (Saturday, Sunday) & 625 & $37.3 \%$ \\
\hline Day off (Holiday) & 230 & $13.7 \%$ \\
\hline Annual leave & 232 & $13.8 \%$ \\
\hline Sick leave & 159 & $9.5 \%$ \\
\hline Total & 1339 & $100 \%$ \\
\hline
\end{tabular}

Source: authors

For those respondents (1339) who answered that during the COVID-19 epidemic they work during nonwork time, we were interested in which time period they most often work. As shown in Table 4, more than half of respondents work in the afternoons (57.1\%) and on weekends (37.3\%). Slightly fewer (31.4\%) respondents work late in the evening. Almost a third of respondents $(21.9 \%)$ work in the morning before the start of their official working hours. $13.8 \%$ of respondents confirmed that they work during the use of annual leave and during the holiday (13.7\%), which is considered a day off work. 9.5\% of respondents worked during the COVID-19 epidemic when they were on sick leave. 
In the research, we were also interested in where public servants performed their work, how they organized their working hours and whether during the COVID-19 epidemic the amount of work increased or decreased or remained at the same level as before. In doing so, we wanted to determine whether there is a link between the volume and frequency of out-of-hours work during the COVID-19 epidemic.

The relationship between workload and frequency of out-of-hours work was verified by Pearson's chi-square test (Table 5).

Table 5: Employees workload during the COVID-19 (SARS-CoV-2) epidemic with work during nonwork time

\begin{tabular}{|c|c|c|c|c|c|c|c|}
\hline $\begin{array}{c}\text { The amount of } \\
\text { work }\end{array}$ & & Daily & $\begin{array}{l}\text { Every } \\
\text { other } \\
\text { day }\end{array}$ & $\begin{array}{l}\text { Once or } \\
\text { twice per } \\
\text { week }\end{array}$ & $\begin{array}{l}\text { Less } \\
\text { often }\end{array}$ & Never & Total \\
\hline \multirow{2}{*}{ Decreased a lot } & Count & 133 & 118 & 141 & 49 & 37 & 478 \\
\hline & $\%:$ & $27.8 \%$ & $24.7 \%$ & $29.5 \%$ & $10.3 \%$ & $7.7 \%$ & $100 \%$ \\
\hline \multirow{2}{*}{ Decreased a little } & Count & 72 & 78 & 222 & 168 & 116 & 656 \\
\hline & $\%$ & $11 \%$ & $11.9 \%$ & $33.8 \%$ & $25.6 \%$ & $17.7 \%$ & $100 \%$ \\
\hline \multirow{2}{*}{$\begin{array}{l}\text { Stayed the same as } \\
\text { before COVID-19 } \\
\text { epidemic }\end{array}$} & Count & 28 & 22 & 86 & 135 & 146 & 417 \\
\hline & $\%$ & $6.7 \%$ & $5.3 \%$ & $20.6 \%$ & $32.4 \%$ & $35.0 \%$ & $100 \%$ \\
\hline \multirow{2}{*}{ Increased a little } & Count & 8 & 7 & 39 & 34 & 37 & 125 \\
\hline & $\%$ & $6.4 \%$ & $5.6 \%$ & $31.2 \%$ & $27.2 \%$ & $29.6 \%$ & $100 \%$ \\
\hline \multirow{2}{*}{ Total } & Count & 241 & 225 & 488 & 386 & 336 & 1676 \\
\hline & $\%$ & $14.4 \%$ & $13.4 \%$ & $29.1 \%$ & $23 \%$ & $20 \%$ & $100 \%$ \\
\hline & & \multicolumn{2}{|c|}{ Value } & $d f$ & \multicolumn{3}{|c|}{$\begin{array}{c}\text { Asymptotic Significance } \\
\text { (2-sided) }\end{array}$} \\
\hline \multicolumn{2}{|l|}{ Pearson Chi-Square } & \multicolumn{2}{|c|}{$318.903^{a}$} & 12 & \multicolumn{3}{|c|}{.000} \\
\hline \multicolumn{2}{|l|}{ Likelihood Ratio } & \multicolumn{2}{|c|}{320.766} & 12 & \multicolumn{3}{|c|}{.000} \\
\hline \multicolumn{2}{|c|}{ Linear-by-Linear Association } & \multicolumn{2}{|c|}{234.922} & 1 & \multicolumn{3}{|c|}{.000} \\
\hline \multicolumn{2}{|l|}{ N of Valid Cases } & \multicolumn{2}{|c|}{1676} & & & & \\
\hline
\end{tabular}

a. 0 cells (0.0\%) have expected count less than 5 . The minimum expected count is 16.78 .

Source: authors

Table 5 shows that the majority of respondents, whose workload remained at the same level as before the COVID-19 epidemic, never work during nonwork time during the epidemic (35\%) to meet their work requirements. For those 
respondents whose workload increased greatly (29.5\%) or increased slightly (33.8\%) or decreased slightly (31.2\%), they also perform work once or twice a week during nonwork time in order to meet work requirements. The differences are statistically significant ( $x 2=318.903 ; \mathrm{dF}=12 ; \mathrm{P}=0.000)$.

During the COVID-19 epidemic, due to a number of measures taken, some public servants changed the location of their work and in this research, we were interested in where public servants performed work during the epidemic. The results of the research are presented in Table 6.

Table 6: Location of work during the COVID-19 (SARS-CoV-2) epidemic

\begin{tabular}{|c|c|c|}
\hline Location of work & $\mathrm{F}$ & $\%$ \\
\hline At home & 453 & $27.0 \%$ \\
\hline A space provided by the employer & 502 & $30 \%$ \\
\hline At home and in a space provided by the employer & 692 & $41.3 \%$ \\
\hline $\begin{array}{l}\text { At different locations where I was sent by my employer } \\
\text { or to whom I went at the request of clients / service users }\end{array}$ & 7 & $0.4 \%$ \\
\hline Other & 22 & $1.3 \%$ \\
\hline Total & 1676 & $100 \%$ \\
\hline
\end{tabular}

Source: authors

Table 6 shows that almost half of the respondents work during the COVID-19 epidemic in combination from home and at the employer's premises (41.3\%), one third of the respondents (30\%) work at the employer's premises and slightly less than one third of the respondents works from home (27\%). Other $(1.3 \%)$, the majority of respondents stated that they work in the field.

We were also interested in how public servants in the Slovenian public administration distribute their working hours during the COVID-19 epidemic and whether their working hours have been lengthened or shortened.

Table 7: Distribution of working time during the COVID-19 (SARS-CoV-2) epidemic

\begin{tabular}{|l|c|c|}
\hline & $\mathrm{F}$ & $\%$ \\
\hline $\begin{array}{l}\text { It is determined by the organization without the possibility } \\
\text { of change }\end{array}$ & 554 & $33.1 \%$ \\
\hline You can adjust your working hours to a certain limit & 995 & $59.4 \%$ \\
\hline You determine your working hours entirely by yourself & 90 & $5.4 \%$ \\
\hline Other & 37 & $2.2 \%$ \\
\hline Total & 1676 & $100 \%$ \\
\hline
\end{tabular}

Source: authors 
Table 7 shows, more than half of the respondents (59.4\%) adjust their working hours to a certain limit during the COVID-19 epidemic. More than a third of respondents (33.1\%) stated that working hours were determined by the organization without the possibility of change. Just over $5 \%$ of respondents set their own working hours. Other, respondents stated that they adjust their working hours in accordance with the agreement regarding online meetings and upon agreement with their superior, according to the needs of the organization and the circumstances and work tasks that they have to perform. Accordingly, we wanted to determine whether there is a link between the frequency of work during nonwork time of public servants and the change in the working hours of respondents during the COVID-19 epidemic.

Table 8: Relationship between the frequency of work during nonwork time and extending or shortening of working hours of respondents during the COVID-19 (SARS-CoV-2) epidemic

\begin{tabular}{|c|c|c|c|c|c|c|c|}
\hline Change of working & ours & Daily & $\begin{array}{l}\text { Every } \\
\text { other }\end{array}$ & $\begin{array}{l}\text { Once or } \\
\text { twice per }\end{array}$ & $\begin{array}{l}\text { Less } \\
\text { often }\end{array}$ & Never & Total \\
\hline & Coun & 153 & 123 & 86 & 4 & 1 & 367 \\
\hline LALCTIUCU a tul & $\%$ & $41.7 \%$ & $33.5 \%$ & $23.4 \%$ & $1.1 \%$ & $0.3 \%$ & $100 \%$ \\
\hline & Coun & 60 & 86 & 267 & 123 & 21 & 557 \\
\hline ExLentuen a di & $\%$ & $10.8 \%$ & $15.4 \%$ & $47.9 \%$ & $22.1 \%$ & $3.8 \%$ & $100 \%$ \\
\hline Remained at the same & Coun & 23 & 14 & 121 & 236 & 302 & 696 \\
\hline COVID-19 epidemic & $\%$ & $3.3 \%$ & $2 \%$ & $17.4 \%$ & $33.9 \%$ & $43.4 \%$ & $100 \%$ \\
\hline & Coun & 5 & 1 & 11 & 19 & 7 & 43 \\
\hline 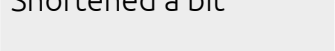 & $\%$ & $11.6 \%$ & $2.3 \%$ & $25.6 \%$ & $44.2 \%$ & $16.3 \%$ & $100 \%$ \\
\hline Chortond tot & Coun & 0 & 1 & 3 & 4 & 5 & 13 \\
\hline JHetceries a tol & $\%$ & $0 \%$ & $7.7 \%$ & $23.1 \%$ & $30.8 \%$ & $38.5 \%$ & $100 \%$ \\
\hline 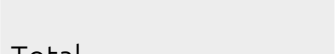 & Coun & 241 & 225 & 488 & 386 & 336 & 1676 \\
\hline 10 dat & $\%$ & $14.4 \%$ & $13.4 \%$ & $29.1 \%$ & $23 \%$ & $20 \%$ & $100 \%$ \\
\hline & & Value & & $d f$ & Asymp & $\begin{array}{l}\text { otic Sign } \\
\text { (2-sided) }\end{array}$ & ícance \\
\hline Pearson Chi-Square & & $1004.002^{\mathrm{a}}$ & & 16 & & .000 & \\
\hline Likelihood Ratio & & 1078.547 & & 16 & & .000 & \\
\hline Linear-by-Linear Associa & ion & 679.304 & & 1 & & .000 & \\
\hline $\mathrm{N}$ of Valid Cases & & 1676 & & & & & \\
\hline
\end{tabular}

a. 5 cells (20.0\%) have expected count less than 5. The minimum expected count is 1.75 .

Source: authors 
Table 8 shows that those respondents whose working hours were significantly extended during the COVID-19 epidemic (41.7\%) work during nonwork time every day. Those respondents whose working hours were slightly extended (47.9\%) work during nonwork time two to three times per week. Those respondents whose working hours were slightly shortened during the COVID-19 epidemic (44.2\%) perform work during nonwork time less often. Those respondents whose working hours remained at the same level as before the COVID-19 epidemic and those whose working hours were greatly reduced never performed work during nonwork time. The differences are statistically significant $(x 2=1000.002 ; d f=16 ; P=0.000)$.

During the COVID-19 epidemic, public servants perform their work with the help of information and communication technology (ICT) which enables them, among other things, to work during nonwork time and to be constantly available to their superiors, colleagues and clients. In the research, we were interested in which ICT is used by public servants when working during the epidemic (Table 9).

Table 9: Use of information and communication technology during nonwork time during the COVID-19 (SARS-CoV-2) epidemic

\begin{tabular}{|l|l|l|l|l|l|}
\hline & N & Minimum & Maximum & Mean & Std. Deviation \\
\hline Personal computer & 1339 & 1 & 5 & 2.68 & 1.78 \\
\hline Laptop & 1339 & 1 & 5 & 3.68 & 1.65 \\
\hline Smartphone & 1339 & 1 & 5 & 3.66 & 1.50 \\
\hline E-tablet & 1339 & 1 & 5 & 1.27 & 0.80 \\
\hline Other & 607 & 1 & 5 & 1.14 & 0.66 \\
\hline
\end{tabular}

Source: authors

The results of the research show (Table 9) that in the period of the COVID-19 epidemic, respondents in the public administration use a laptop (3.68) and a smartphone (3.66) the most on average during nonwork time, slightly less, they use a personal computer (2.68) and the e-tablet (1.27).

In the survey, we were also interested in how many working contacts per week, public servants receive via ICT work during nonwork time during the COVID-19 epidemic (Table 10). 
Table 10: Number of working contacts received per week during nonwork time during the COVID-19 (SARS-CoV-2) epidemic

\begin{tabular}{|l|c|c|c|c|}
\hline & $\begin{array}{c}\text { Business } \\
\text { e-mails per } \\
\text { week: }\end{array}$ & $\begin{array}{c}\text { Business } \\
\text { phone calls } \\
\text { per week: }\end{array}$ & $\begin{array}{c}\text { Business text messages } \\
\text { (e.g. text messages, } \\
\text { mobile applications, } \\
\text { social networks) per } \\
\text { week: }\end{array}$ & $\begin{array}{c}\text { E-meetings (Zoom, } \\
\text { MS Teams, Cisco } \\
\text { Webex, Skype, } \\
\text { itd.) per week: }\end{array}$ \\
\hline N & 1338 & 1338 & 1335 & 1334 \\
\hline Mean & 32.0 & 10.4 & 8.3 & 1.0 \\
\hline Std. Deviation & 83.3 & 25.3 & 124.6 & 3.0 \\
\hline
\end{tabular}

Source: authors

Table 10 shows that respondents receive the majority of e-mails and business phone calls during the COVID-19 epidemic during non-working hours. On a weekly basis during nonwork time, respondents receive an average of 32.0 e-mails, 10.4 business phone calls and 8.3 business text messages (e.g. in the form of a text message or a message via a mobile application or social networks). One e-meeting per week is organized (Zoom, MS Teams, Cisco Webex, Skype, etc.) on average.

\section{Discussion}

As part of the research we wanted to determine whether public servants in public administration in Slovenia work during nonwork time and how they respond to work demands (due to the use of information and communication technology - ICT) during the COVID-19 (SARS-CoV-2) epidemic. We also wanted to find out how many public servants report that the volume of their work has increased, compared to the time period before the epidemic, and the fact that they are therefore working during nonwork time.

Based on the results of our research, we find that $80 \%$ of surveyed public servants in Slovenian public administration work during nonwork time, while $20 \%$ of respondents confirmed that they never work during nonwork time during the COVID-19 epidemic. Our findings are in line with the results of the Eurofound (2021) and McCulley (2020, cited in ILO, 2020) surveys, which confirmed that during the COVID-19 epidemic, on average more than half of the respondents worked during nonwork time in Slovenia (55\%). The results of our research show that those respondents who work work during nonwork time during the COVID-19 epidemic most often work in the late afternoon, after work, on weekends and late in the evening, which was also confirmed by Reisenwitz (2020, cited in ILO, 2020), Gschwind and Vargas (2019) and Houdmont et al. (2018). In accordance with the results and findings, we therefore confirm the Hypothesis 1 which states: "During the COVID-19 (SARS-CoV-2) epidemic, more than half of the surveyed public servants in public administration work during nonwork time." 
In the survey, the majority of respondents confirmed that they work in combination from home and at the employer's location, with more than half of the respondents adjusting their working hours to a certain limit during the COVID-19 epidemic. From which we conclude that the respondents meant flexible working hours, as regulated in the Decree on working hours in state administration bodies, which stipulates that public servants may schedule working hours within the prescribed daily, weekly and monthly work obligations. It is interesting to note that those respondents whose working hours increased or slightly increased during the COVID-19 epidemic or slightly decreased, also work during nonwork time. While those respondents whose working hours did not change compared to the time period before the epidemic mostly never worked during nonwork time. There is also a statistically significant correlation ( $\mathrm{x} 2=318.903 ; \mathrm{df}=12 ; \mathrm{P}=0.000$ ) between the amount of work that public servants have to do during the epidemic and work during nonwork time. Based on this, we confirm Hypothesis 2: "Work during nonwork time during the COVID-19 (SARS-CoV-2) epidemic is performed by those public servants in the public administration whose workload has increased."

Based on the results of the research, we find that public servants in public administration in Slovenia work during nonwork time because they were not able to perform work tasks during working hours and because information and communication technology (ICT) allows them to do so. During non-working hours, public servants also use ICT to respond to the work requirements of their superiors, co-workers and clients and perceive them as work obligations that they must fulfill. The results of our research also show that public servants also perform work during the use of annual leave during the COVID-19 epidemic, which was confirmed by $13.8 \%$ of respondents and during their sick leave, which was confirmed by $9.5 \%$ of respondents. Similar results were found in the study by Houdmount et al. (2018).

We believe that the measures introduced during the COVID-19 epidemic affect the organization and the dynamics of work of public servants. In our research, we were interested in which ICT respondents use the most during non-working hours and how many work contacts they receive through it on average per week, as we know that the physical separation of co-workers and work teams affected work tasks and communication between employees in the public administration. The results of the survey showed that respondents use a laptop and a smartphone the most, receiving the most e-mails and business phone calls on average per week. Similar findings have been made in other studies (DeFilippis et al., 2020; Reisenwitz, 2020; cited in ILO, 2020; Gschwind and Vargas, 2019; Vayre and Vonthron, 2019). Based on this, we conclude that ICT is extremely important for public servants and enables them to work during nonwork time or their availability for work.

The results of the research conducted in the public administration on the performance of public servants during nonwork time during the COVID-19 epidemic are also important due to the theoretical and practical contribution, which we are presenting below. 
An important contribution of our work to theoretical knowledge is a better understanding of the concept of so-called time during nonwork time. This means a rest period intended for relaxation, entertainment and elimination of tiredness caused by work. Non-working hours include daily and weekly rest and the right to annual leave and sick leave for the employee. The performance of work during nonwork time is mainly influenced by the use of information and communication technology (ICT), due to which employees are not only constantly available, but they also respond to work demands. With the results of our research, we will further contribute to the theoretical knowledge and literature, as this research confirmed that more than half of public servants in the Slovenian public administration work during nonwork time during the COVID-19 epidemic. Compared to the time before the COVID-19 epidemic, the volume of work of most public servants increased during the epidemic, and their working hours also increased. As a result, public servants work and respond to work demands during nonwork time, which ICT allows them to do. This is important both for theoretical knowledge and for future research of work during nonwork time of public servants in relation to their extended availability. Our work is important for theory (and practice) also because our research found that there is a certain share of public servants in public administration who perform work during the use of annual leave and during sick leave.

The results of our research have several practical implications. The findings are crucial for public administration bodies and organizations in terms of the organization and duration of working hours and the organization and manner of performing the work of public servants. The results are essential for understanding the issue of work during nonwork time in the Slovenian public administration. Awareness of senior staff about the increase in the amount of work to be done by public servants during the COVID-19 epidemic and the findings of a survey on the large proportion of public servants who are constantly accessible through information and communication technology (ICT) or available for work requirements are important for introduction of measures and changes regarding the organization and duration of working hours and rest periods. The rest period is intended for public servants to engage in private activities aimed at their relaxation, and not to perform work tasks during this time and respond to work requests. Rest time is essential for every individual, as it affects their well-being and health. Our research is also important for practice from the perspective of acquainting the state as an employer and policy makers with the results, with the aim of limiting or reducing the problem of working during nonwork time. Senior public administration staff also gain insight into the duration of working hours and rest periods of their employees and the manner in which they work. In this way it will be necessary to consider both senior staff and other public servants regarding the organization of working hours and work. In addition, the results of the research are important for the introduction of practical measures in order to improve the well-being and health of public servants. 


\section{Conclusion}

The organization and duration of working time and rest time are essential for every individual. When employees work during nonwork time, they extend their availability, which has the effect of deteriorating the well-being and health of employees. Especially from the point of view of well-being and health of employees, it is important that they relax, rest and leave work during non-working hours and stay away from work for a certain period of time, which contributes to their recovery. Global changes, such as the outbreak of the COVID-19 (SARS-CoV-2) pandemic and the widespread use of information and communication technology (ICT), are affecting public servants. The results of our research show that $80 \%$ public servants in public administration work during nonwork time, and this information should be worrying, as employees work during rest periods. Based on the results of our research we suggest that further research of extended availability on nonwork time of public servants make sense. 


\section{References}

Ahrendt, D. et al. (2020). Living, working and COVID-19. Luxembourg: Publication Office of the European Union.

Ahrendt, D. et al. (2020). Living, working and COVID-19: Methodological Annex to Round 1. Luxembourg: Publication Office of the European Union.

Aleksynska, M. et al. (2019). Working conditions in a global perspective. ILOEurofound report. Luxembourg: Publications Office of the European Union.

Anttila, T. et al. (2009). Ansiotyö kotona: Yleisyys, minaispiirteet, seuraukset ja hallinta palkansaajilla (Gainful employment at home: Prevalence, characteristics, consequences and management of wage and salary earners). Tampere: The Finnish Work Environment Fund.

Buzeti, J. (2020). Association between Field of Work, Years of Service, and Sickness Absenteeism in Public Administration. Organizacija, 53(1), pp. 53-67. doi: 10.2478/orga-2020-0004.

DeFilippis, E. et al. (2020). Collaborating during coronavirus: The impact of covid-19 on the nature of work. Working Paper No. 27612, pp. 1-32.

Directive 2003/88/EC OJ L 299, 18.11.2003, pp. 9-19.

Eurofound (2021). Working during COVID-19. Cambridge: National Bureau of Economic Research. At <https://www.eurofound.europa.eu/sl/data/covid-19/ working-teleworking>, accessed 14 January 2021.

Evropska komisija (25. 4. 2017). Razlagalno sporočilo o Direktivi 2003/88/ES Evropskega parlamenta in Sveta z dne 4. november 2003 o določenih vidikih organizacije delovnega časa. Uradni list EU, št. 2017/C 165/01.

Genin, É. (2016). Proposal for a theoretical framework for the analysis of time porosity. International Journal of Comparative Labour Law and Industrial Relations, 32(3), pp. 280-300.

Gschwind, L. and Vargas, O. (2019). Telework and its effects in Europe. In J., C. Messenger. Telework in the 21st Century. An Evolutionary Perspective. Switzerland: International Labour Organization, ILO, pp. 36-75.

Hooftman, W. E. et al. (2015). Nationale Enquête Arbeidsomstandigheden 2014 - Methodologie en globale resultaten. Leiden: TNO.

Houdmont, J., Elliot-Davies, M. and Donnelly, J. (2018). Leaveism in English and Welsh police forces: baseline reference values. Occupational Medicine, 68(9), pp. 1-21. doi:10.1093/occmed/kqy147.

Instituto Nacional de Salud e Higiene en el Trabajo (INSHT). (2011). VII Encuesta Nacional de Condiciones de Trabajo. Madrid: Instituto Nacional de Salud e Higiene en el Trabajo. pp. 1-57.

International Labour Organization (2020). Teleworking during the COVID-19 pandemic and beyond. Geneva: International Labour Office.

Lutz, S., Schneider, F. M. and Vorderer, P. (2020). On the downside of mobile communication: An experimental study about the influence of settinginconsistent pressure on employees' emotional well-being. Computers in Human Behavior. doi: 10.1016/j.chb.2019.106216.

McCulley, L. (2020). Lockdown: Homeworkers putting in extra hours - instant messaging up 1900\%. At <https://www.thehrdirector.com/business-news/ the-workplace/new-data-over-a-third-38-admit-to-working-longer-hourswhen-working-from-home/>, accessed 27 April 2020. 
Ojala, S. (2011). Supplemental work at home among Finnish wage earners: involuntary overtime or taking the advantage of flexibility? Nordic Journal of Working Life Studies, 1(2), pp. 77-97. doi: 10.19154/njwls.v1i2.2346.

Parent-Thirion, A. et al. (2017). 6th European Working Conditions Survey. Publications Office of the European Union, Luxembourg. pp. 148-165.

Directive 2003/88/EC OJ L 299, 18.11.2003, pp. 9-19.

Randstad. (2012). Las tecnologías destruyen las fronteras entre vida privada y laboral. At <www.randstad.es>, accessed 21 April 2020.

Reisenwitz, C. (21. 4. 2020). How COVID-19 is impacting workers' calendars. Clockwise blog. At <https://www.getclockwise.com/blog/how-covid-19-isimpacting-workers-calendars>, accessed 21 April 2020.

Sutela, H. and Lehto, A., M. (2014), Työolojen muutokset 1977-2013. Helsinki: Statistics Finland.

Senčur Peček. D. (2017). Delovni čas v dobi stalne dosegljivosti. Delavci in delodajalci, 17(2-3), pp. 155-178.

Tičar, B. and Rakar, I. (2011). Pravo javnega prava. Maribor: Inštitut za lokalno samoupravo in javna naročila.

Tipping, S. et al. (2012). The Fourth Work-Life Balance Employee Survey. London: Department for Business Innovation and Skills.

Thörel, E., Pauls, N. and Göritz, A. S. (2020). Are the effects of work-related extended availability the same for everyone? Revistade Psicologia del Trabajo y delas Organizaciones, 36(2), pp. 147-156. doi:10.5093/jwop2020a14.

Trygg, K. (2014), Arbetets geografi - Kunskapsarbetets organisation och utförande i tidrummet. Stockholm: Department of Human Geography, Stockholm University, pp. 1-237.

Unionen. (2013). Jobbet alltid närvarande - en studie om tjänstemännens gränslösa arbetsliv. Unionen, Malmö, pp. 1-34.

Uredba o delovnem času v organih državne uprave. Uradni list RS, št. 115/07, 122/07 - рорг., 28/16, 40/17 in 44/19.

Vayre, E. and Vonthron, A. M. (2019). Identifying Work-Related Internet's Usesat Work and Outside Usual Workplaces and Hours-and Their Relationships with Work-Home Interface, Work Engagement, and Problematic Internet Behavior. Front. Psychol., 10(2118), pp. 1-15. doi:10.3389/fpsyg.2019.02118.

Walrave, M. and De Bie, M. (2005). Teleworking @ home or close to home. Attitudes towards and experiences with homeworking, mobile working, working in satellite offices and telecentres. Antwerp: University of Antwerp, Faculty of Political and Social Science.

Zakon o delovnih razmerjih (ZDR-1). Uradni list RS, št. 21/13, 78/13 - popr., 47/15 - ZZSDT, 33/16 - PZ-F, 52/16, 15/17 - odl. US, 22/19 - ZPosS in 81/19.

Zakon o javnih uslužbencih (ZJU). Uradni list RS, št. 63/07 - uradno prečiščeno besedilo, 65/08, 69/08 - ZTFI-A, 69/08 - ZZavar-E, 40/12 - ZUJF in 158/20 ZIntPK-C. 